\title{
TENSIONS IN INTELLIGENT DESIGN'S CRITIQUE OF THEISTIC EVOLUTIONISM
}

\section{Kojonen, Erkki Vesa Rope}

2013-06

Kojonen , E V R 2013 , ' TENSIONS IN INTELLIGENT DESIGN'S CRITIQUE OF THEISTIC EVOLUTIONISM ' , Zygon , vol. 48 , no. 2 , pp. 251-273 . https://doi.org/10.1111/zygo.12010

http://hdl.handle.net/10138/157575

https://doi.org/10.1111/zygo.12010

submittedVersion

Downloaded from Helda, University of Helsinki institutional repository.

This is an electronic reprint of the original article.

This reprint may differ from the original in pagination and typographic detail.

Please cite the original version. 


\title{
Tensions in Intelligent Design's Critique of Theistic Evolutionism
}

\author{
Erkki Vesa Rope Kojonen
}

\begin{abstract}
"Intelligent Design" (ID) is a contemporary intellectual movement arguing that there is scientific evidence for the existence of some sort of creator. Its proponents see ID as a scientific research program and as a way of building a bridge between science and theology, while many critics see it merely as a repackaged form of religiously motivated creationism: both bad science and bad theology. In this article, I offer a close reading of the ID movement's critique of theistic evolutionism (TE) and argue that this critique is ultimately in tension with the movement's broader thought.
\end{abstract}

\section{Introduction}

The Intelligent Design movement argues that the order of nature provides scientific evidence of the existence of an "intelligent designer", typically believed to be the God of the Bible. Intelligent Design is a counter-reaction to the atheistic evolutionism of thinkers like Richard Dawkins (1991), who argue that evolutionary theory shows the unnecessity of a Creator. However, from its beginnings ID has also critiqued theistic evolutionism, which accepts both the doctrine of creation and the mainstream scientific theory of Darwinian evolution. This article has a twofold purpose. First, I aim to increase understanding of Intelligent Design and its central differences from theistic evolutionism. Second, I will argue that ID's critique of theistic evolutionism is ultimately in tension with the movement's broader thought. Thus, this critique should be abandoned or substantially modified even by proponents of ID.

Theistic evolutionism and ID have some similarity, because both oppose atheistic evolutionism. In principle, Intelligent Design seeks to unify all those who believe that there is evidence for design in the cosmos and oppose naturalism under one "big tent" (e.g. Nelson 2002). But while both old-earth and young-earth positions as well as directed non-Darwinian evolution are acceptable under the big tent, theistic evolutionism is typically seen as an inadequate response to the problems posed by atheistic evolutionism. Thus the official ID websites Evolution News and Views and Uncommon Descent contain frequent critiques of TE alongside critiques of naturalism and Darwinian evolutionary theory. A recent example of ID's critique of TE is the 2010 collection God and Evolution edited by Discovery Institute fellow Jay Richards.

The compatibility of evolution and Christian belief has been defended in many works. A problem is posed by the variety within TE. By TE, I mean here broadly the combination of belief in God as creator, who directed, planned or influenced the course of evolution, and mainstream Darwinian evolutionary theory. Ian G. Barbour (1997) has defined three primary varieties of TE. On the first view, "God controls events that appear to be random". On this view, the process of evolution is understood to be under God's control, though his supervision is not included in scientific theories of our origins. On the second view, "God designed a system of law and chance." God set up the universe at the beginning in a way that makes evolution possible. On the third 
view, "God influences events without controlling them." On this view, God is understood to give the world much freedom to evolve. God influences evolution through his love, but does not control it.

Because of the variety within TE, many of those who can be classified as TE's using the above definition themselves prefer another term, such as "evolutionary creationism" or "BioLogos" to define their view. However, in this article I will use the term "theistic evolutionism" in the broad sense. The variety within TE means that not all TE's will agree with everything I identify as a possible TE response to the ID theorists' critique. In any case, common responses to the purported problems posed by Darwinism for the doctrine of creation have been that (1) we can separate between the scientific theory of biological evolution, which is compatible with Christianity, and the metaphysical worldview of atheistic evolutionism, which is not; (2) design and evolution need not be opposed, since God could have designed the process of evolution; (3) we do not need scientific evidence to confirm the doctrine of creation, because the doctrine does not operate on the same level as scientific theories, and religious doctrines have different grounds than scientific theories.

Intelligent Design is highly controversial and has been subject to much critique. There has already been much discussion between proponents of ID and theistic evolutionists (e.g. Johnson \& Lamoureux 1999, Pennock 2001, Dembski \& Ruse 2004). A problem is posed by the emotionally charged nature of the debate. As Nathaniel C. Comfort $(2007,3)$ notes, "one point on which anti-Darwinists and anticreationists agree is that this is a pitched battle between dogmatic religious fanatics on the one hand, and rigorous, fair-minded scientists on the other. However, which side is which depends on who you read." In addition to the above points about the reconciliation of evolutionary theory and religious belief, typical critiques of ID include (1) the scientific defense of evolutionary theory (Miller 2002), (2) the defense of metholodogical naturalism as a principle guiding scientific theories and excluding ID (Ruse 1996), (3) the critique of ID as a "God of the gaps" -argument (Van Till 2001), and (4) the critique of ID based on the problem of natural evil (Ayala 2007a). Analysts of these arguments disagree on the effectiveness of some critiques. For example, Jeffrey Koperski (2008) and Del Ratzsch $(2001 ; 2002)$ have shown the complexity of the issues. This paper takes a different approach by focusing on inner tensions within ID thought rather than on the common critiques of ID.

ID emphasizes the importance of the empirical evidence in deciding our beliefs about natural history, rather than philosophical or theological reasoning. For example, the Discovery Institute (2011) defines ID as "a scientific research program" and Thomas Woodward $(2003,195)$ argues that ID is about "respected professors at prestigious secular universities ... rising up and arguing that (1) Darwinism is woefully lacking factual support and is rather based on philosophical assumptions, and (2) empirical evidence, especially in molecular biology, now points compellingly to some sort of creative intelligence behind life." Phillip Johnson (1995, appendix) also gives some theological reasons for this emphasis on the empirical evidence: because God could have created the different forms of life in any way, it is up to empirical research to find out how God did it. Consistent with this, William Dembski $(1999,112)$ argues that "the design theorists' critique of Darwinism begins with Darwinism's failure as an empirically adequate scientific theory, not with its supposed incompatibility with some system of religious belief".

However, ID theorists also use philosophical and theological arguments against TE. It is argued that TE fails to resolve the problem posed to theism by atheistic Darwinism. ID's critique of theistic evolutionism is partly about the definitions of design and Darwinism. The movement sees Darwinian evolutionary theory as a materialistic way of thought which is in direct competition with the theistic way of thought. Because of this, 
combining theism and Darwinism is seen as disingenuous. In the first half of my article, I will analyse this critique in more detail. I will begin by analysing TE's and ID's different definitions of design, and will then proceed to analyse the proposed conflict between design and Darwinism as competing explanations. In the latter half of my article, I will analyse ID's evidentialistic thought which underlies its critique of theistic evolutionism. As will be seen, the crucial problem in theistic evolution for the ID theorists is their belief that TE does not provide sufficient evidence for theism and against atheistic Darwinism. I will limit myself here to arguments which can be found in the writings of major ID theorists like Phillip Johnson, William Dembski, Michael Behe, Jonathan Wells and Stephen Meyer. However, there is variety within the ID movement, and not all ID theorists make the same critiques of theistic evolutionism.

\section{Definitions of Design and Evolution}

Can belief in design and evolution be combined? This depends on the definitions of design and evolution. Conceiving of design as a process of planning, it seems entirely possibly to combine design and material mechanisms as complementary, rather than exclusive modes of explanation. Plato's demiurge, for example, created by using matter's existing properties, not contrary to laws of nature. For the death of Socrates, Plato saw several causes. While the poison drank by Socrates was the material cause of his death, this does not mean that the political situation of Athens and the purposes of both Socrates and his opponents are not important to note. (Sedley 2007) If evolution is understood similarly as the process the Creator chose to employ, believing in both creation and evolution does not seem contradictory.

There is some temptation to see the conflict between ID and theistic evolutionism as arising from different definitions of design. Theistic evolutionists could be understood to define design without opposing it to natural causes, whereas ID theorists often juxtapose chance, necessity and design as alternative modes of explanation. (E.g. Dembski \& Witt 2008). In critiques of ID (E.g. Van Till 2001), it is often understood to imply an interventionistic account of natural history, where nature requires the constant miraculous activity superceding the laws of nature to produce the complexity of life. However, this is perhaps a too simplistic portrayal of the debate, because the central ID theorists understand the possibility for combining natural causes and design. Michael Behe thus writes that the only alternatives are not "a cartoon world, where genies and fairies swirl about endlessly dispensing magic, or a world of relentless materialism where, say, the charitable work of a Mother Teresa is explained only in terms of evolutionary selection coefficients." (Behe 1999) Behe argues that the designer worked through directing a natural process of evolution, perhaps by programming it into the workings of the universe. (Behe 2007, chapter 10) Dembski similarly argues that design could be inserted into the universe in quantum events invisible to the natural sciences without violating the laws of nature (Dembski 2002, 333-337) or that the designer could work through programming the course of evolution (Dembski \& Marks 2011).

I propose that the conflict has more to do with ID's and TE's different definitions of evolution, rather than different definitions of design. Dembski and Jonathan Wells (2007) distinguish between several different meanings of the word "evolution", most of which they believe to be compatible with theism and ID. First, evolution can mean simply change over time or minor changes within existing organisms. Second, it can mean the idea of common descent. Third, it can mean evolution through the Darwinian mechanism of mutation and 
selection. Fourth, it can mean evolution through some other evolutionary mechanism such as described in the theories of endosymbiosis or neutral theory. For the ID theorists, all of these forms of evolution are compatible with design, as long as unguided evolutionary mechanisms are not seen as sufficient to explain life without design.

Within ID, Darwinian evolution is seen as a special type of natural explanation which excludes design. As Jonathan Wells argues, "it is not evolution in general, but Darwinism's exclusion of design, that ID proponents reject." (Wells 2010,119) Theistic evolutionism in the sense of belief in evolution actively directed by God is held to be a possible way of believing in creation. However, this form of directed evolution is believed to be in contradiction with standard Darwinism. (Meyer 2010, 147; Johnson 1993, 4n1) According to Johnson (2001, 436), "'Evolution', honestly understood, is not just a gradual process of development that a purposeful Creator might have chosen to employ. It is, by Darwinist definition, a purposeless and undirected process that produced mankind accidentally."

ID theorists thus understand mainstream Darwinian evolutionary theory to include the denial of purpose and direction to evolution. They share Richard Dawkins' understanding of evolution as the "blind watchmaker" (e.g. Johnson 2001). The contrast the ID theorists make is between the origin of the species as purposeful and directed in the theistic story and evolution as purposeless and undirected in the naturalistic story of origins. (Richards 2010, 7-25) They see Darwinism as an attempt to reduce the teleology of organisms completely to the purposeless movement of matter, whereas theism explains the movement of matter teleologically. Put this way, Darwinism is in contradiction with any theistic view which argues that God intended to create some forms of life.

On this level, the debate between ID and TE is about the definition of evolution (e.g. Lamoureux \& Johnson 1999). Some theistic evolutionists, such as Francisco Ayala (2007b), do argue that the Darwinian process produces "design without a designer". But a more typical theistic response to Darwinism has been to separate between the scientific theory of evolution and the metaphysical idea that evolution was unguided. (e.g. Cunningham 2010, Plantinga 2011) Many TE's do not believe that mainstream evolutionary biology implies that evolution must be ultimately non-purposeful. The ID theorists' view is that these TE's are constructing their own view of what "Darwinism" means, bypassing the real meaning of the term "Darwinism" in the scientific community. Phillip Johnson thus argues that a TE who does not believe that undirectedness is a part of evolutionary theory should argue this with the scientific community, rather than the ID movement (Johnson \& Lamoureux 1999).

Both ID'ers and TE's acknowledge the influence of the metaphysical interpretation of evolution in the scientific community, but present different strategies for answering the problem. TE's generally believe that separating the two forms of "Darwinism" is possible, and evolution can be understood as just a scientific theory. The ID theorists see a close connection between metaphysical Darwinism and scientific Darwinism, and therefore attack metaphysical Darwinism by attacking scientific Darwinism. Thus Johnson (Johnson \& Marks 2010, 49-55) calls Darwinism an "episteme, a way of thinking about things in general" and writes that theistic evolutionists miss the point of Darwinism, which is fundamentally reductionistic, materialistic and atheistic. Darwinian evolution "must be a rock of certainty, while everything else is dissolved into shifting sand by the acid of reductionism". In his argument, Johnson imitates atheist evolutionists like Richard Dawkins and Daniel 
Dennett, calling evolution an "universal acid" and arguing that it is quite logical to extend Darwinian materialism into an account of the basis of reality, if the theory is true. (Johnson \& Marks 2010, 55)

Johnson admits the possibility for a theistic evolutionist to reject the Darwinian episteme while accepting Darwinism as a scientific theory, though he himself believe that this separation is only barely possible. (Johnson \& Marks 2010, 49-55) This very strong link between Darwinism as a metaphysical worldview and the scientific theory of evolution can be questioned. Why is it not possible to accept Darwinian evolution as a probable biological theory and yet not accept the "Darwinian episteme"? It seems that some positive philosophical arguments should be given before we are justified in selecting Darwinism as our starting point in interpreting all other areas of life. Could we not rather interpret evolutionary biology's meaning for our life based on what we know through other means, such as through our everyday experience, our philosophy and our religion? It seems difficult to base any whole way of thought on just scientific discoveries. (Stenmark 2001)

In favour of Johnson's argument, it is indeed based on the way many Darwinians themselves understand the implications of evolution. (Haught 2003, Johnson \& Lamoureux 1999) For some Darwinists, the theory also does seem to be based on a naturalistic way of thought, rather than just the evidence. For instance, Richard Dawkins argues in his book the Blind Watchmaker that Darwinian evolution would be a better explanation than design even if we had no evidence. (Dawkins 1991, 317). This is because a designer would, according to Dawkins, be more complex than the designed object, and the purpose of explanation is to reduce (Dawkins 1991, chapter 6; Dawkins 2006). Many commentators have remarked that Dawkins has constructed rules of rationality which make something like Darwinian evolution the only possible explanation for life as an a priori.(Orr 2007, Plantinga 2007) However, for many others the perception that there is evidence for evolution is a far more important reason for believing in evolution than materialistic philosophy. It does not follow that we could not have good evidence for Darwinian evolution even if the "Darwinian episteme" were abandoned. As Bradley Monton $(2009,62)$ has argued, even a scientist adopting Johnson's "theistic realism" would not be inclined to accept "God did it" as an explanation, but would seek for further understanding and the explanation which fits the evidence best. Supposing that the evidence best fits the theory of Darwinian evolution, a "theistic realist" should accept Darwinian evolutionary theory.

It seems difficult to settle the disagreements about the implications of evolutionary theory simply by polling evolutionary biologists and asking them whether Darwinism has metaphysical implications. The question of implications is a philosophical one, and the arguments for and against any such understanding of evolutionary theory can be evaluated.

\section{Darwinism and Design as Competing Explanations}

Fortunately, the ID theorists have expanded their critique of theistic evolutionism to analyse the arguments for understanding design and Darwinism as competing explanations for the same biological data. For example, Dembski (1998a, 110) argues that "theistic evolution takes the Darwinian picture of the biological world and baptizes it, identifying this picture with the way God created life. When boiled down to its scientific content, however, theistic evolution is no different from atheistic evolution, treating only undirected natural processes in the origin and development of life." Referring to Occam's razor (the principle of parsimony), Dembski argues that we should not multiply explanations beyond that which is required to explain the evidence. If the Darwinian 
mechanism is sufficient to explain the evolution of life, the supposition of a divine guidance becomes unnecessary. Thus consistent theistic evolutionists should either argue that evolution is directed, in opposition to Darwinism, or give up the label "theism" as superfluous to their understanding of evolution. Within ID, design and Darwinism are thus thought to occupy the same explanatory space. If one believes in Darwinism, design becomes unnecessary, and vice versa.

I will analyse this critique of TE in more detail by way of two examples: Stephen Meyer's (2010) critique of Denis Lamoureux' evolutionary creationism and William Dembski's (2004) critique of Simon ConwayMorris' view that the phenomenon of convergence allows us to see a direction in evolution.

According to Lamoureux, "the Creator established and maintains the laws of nature, including the mechanisms of a purpose-driven teleological evolution."(Meyer 2010, 14) Lamoureux argues that the mechanisms of biological evolution are sufficient to explain evolution within methodologically naturalistic science. However, he also affirms the value of the design argument outside of science, even calling his view "intelligent design." In Lamoureux' view, God has made the evolution of humans possible already with his initial act of creation, like a brilliant billiard player can sink all balls with one shot. While no references to design are necessary on the level of proximate biological explanations, ultimately all of the workings of nature reveal the existence of its Creator. Thus nature cannot ultimately be properly understood without reference to its Creator. (Johnson \& Lamoureux 1999)

For Meyer (2010), Lamoureux' harmonization of theism and Darwinism does not differ sufficiently from naturalism in its explanation of the origin of life. Meyer perceives the possible explanations to be the following.The information which makes life possible could come directly from the mind of the designer, or it could be mediated by deterministic natural laws causing life to self-organise. The first option would differ from naturalistic theories, and the second possibility is (for Meyer) falsified by scientific results. The third option would be to base a theory of life's origins on contingent, accidental chemical events, which natural selection then works on. But on this model, Meyer believes that random chance would do the work of creation instead of a personal Creator. Thus for Meyer, there is no plausible position which combines theism and naturalistic explanations for the origin of life.

Meyer's conclusion in critiquing Lamoureux is that "it is difficult to see how Lamoureux's theory - differs in substance from conventional materialistic theories of evolution that rely on undirected contingency and deny any intelligent guidance or direction in the history of life." (Meyer 2010, 162) Meyer's argument is that the deity does not have a much greater role in this sort of theistic evolutionism than in standard materialist theories of life's origins. Thus belief in the deity's direction in evolution is explanatorily unnecessary. Meyer acknowledges that Lamoureux believes the creator designed natural laws which allow for the interplay of natural laws and natural events to create living organisms. However, Meyer wants the scientific evidence to reveal the Creator's active involvement in the creation of life beyond the laws of nature: an affirmation of theism instead of mere deism.

William Dembski (2004) makes many of the same points in his critique of Simon Conway-Morris' defence of theistic evolution. Paleontologist Conway-Morris develops his argument in his book Life's Solution: Inevitable Humans in a Lonely Universe (2003). Evolutionary convergence means that similar features have evolved several times independently during the course of evolution. According to Conway-Morris, convergences show that the course of evolution is to some extent determined by the natural laws and conditions of our 
universe. Extrapolating from this, it could be that even the emergence of human-like organisms is ultimately determined by the natural laws. For Conway-Morris, this is supporting evidence for the belief that God directs the course of Darwinian evolution through such natural constraints.

But for Dembski (2004), Conway-Morris' solution is not a sufficient response to the challenge of atheistic Darwinism: "Ultimately, the problem here is a fundamental tension inherent in theistic evolution. As is characteristic of theistic evolution, Life's Solution challenges materialism as a metaphysical position but not as a regulative principle for science." For Dembski, Conway-Morris' argument is too weak, because atheistic interpretations of evolution remain somewhat plausible even after the evidence from convergence. Though Conway-Morris has given some evidence that the course of evolution is limited to fixed paths, he has not provided scientific evidence that biological evolution requires design. Because design is not a necessary part of the scientific explanation of evolution, it can be excluded by Occam's razor.

Both Dembski and Meyer emphasize the need for scientific evidence to determine the limits of natural processes in producing the known properties of biological organisms. Both thinkers want the scientific evidence to reveal limits in the capabilities of naturalistic evolutionary processes. To counter the metaphysical interpretation of Darwinism, they want strong and scientific evidence of design. The emphasis of the importance of scientific evidence for design is thus fundamental to ID's critique of Intelligent Design. Below, I will focus on this aspect of ID thought further. Before that, I will ask whether the ID movement's critique does justice to theistic evolutionism.

While Meyer is correct that Lamoureux's explanation does not differ from materialist Darwinists on the level of biological details, it does not follow that Lamoureux's evolutionary creationism contains no substantial differences from atheistic views. After all, Lamoureux agrees with the proponents of ID, and against materialism, that (1) the ultimate basis of reality is personal, (2) there is evidence for design in nature, and (3) atheistic interpretations of nature can be opposed with rational arguments. Lamoureux is not an atheist or a deist, but believes in a God who is active in the world, even performing miracles. Here it seems that the ID theorists' critique of theistic evolutionism carries them far from their "big tent" strategy, an attempt to unify those who believe in design and oppose scientific atheism.

Suppose that theistic evolutionists' account of chemical and biological evolution does not differ on the level of biological science from those of atheistic evolutionists, as Meyer and Dembski argue. Even if there is no design required on the level of proximate biological explanations, it does not follow that there is no design required on a broader point of view, for example when considering underlying explanatory levels. Lamoureux' argument is that the very possibility of Darwinian evolution depends on the existence of natural laws and conditions which biology takes for granted. If natural laws are designed, then the possibility of Darwinian evolution requires design. If that is the case, then the apparently purposeful complexity in biological organisms depends on design, and cannot be said to be produced without design. Although design is not a proximate cause of evolution, it can be the ultimate explanation for its possibility. As Del Ratzch $(2010,130)$ has argued, "design is not a causal irrelevance" in explaining biological complexity, if the natural laws were designed.

Dembski argues that Conway-Morris does not present sufficient evidence for the teleology of evolution. Conway-Morris point was arguably not to present undeniable evidence that evolution was directed, but rather to argue that theistic evolution is a coherent and rational possibility. Conway-Morris shows that it is an error to think of mutation and selection as the only important factors in evolution. Rather, the different biological forms 
can be seen as built into the laws of nature. Conway-Morris' argument shows one way in which God could direct evolution, even though the mutations seem accidental from a scientific point of view. It could simply be that all of the possible natural events will tend to lead evolution along certain paths which are predetermined by the characteristics of the universe. In this way, God could make even accidental evolutionary events work towards his purposes in creation. Conway-Morris does seem to show this, even if he does not deliver a knockdown argument in favour of a theistic understanding of evolution.

Perhaps the ID theorists have accepted atheistic interpretations of evolutionary theory too readily. As another example, Phillip Johnson has accepted Dawkins' interpretation of Darwinian evolution functions as a "consciousness-raiser" which shows that teleology can be reduced to material processes. According to Dawkins (2006, 139), "a deep understanding of Darwinism teaches us to be wary of the easy assumption that design is the only alternative to chance, and teaches us to seek out graded ramps of slowly increasing complexity. - After Darwin, we should feel, deep in our bones, suspicious of the very idea of design." Dawkins argues that since Darwinism shows that reductionistic explanations for teleology are possible, it provides grounds for the reduction of all teleology to non-intentional material causes. Johnson agrees with Dawkins. He believes that Darwinism lends credence to such reductionism, and thus includes a way of thought which is contradictory with cosmic design arguments as well. (Johnson \& Marks 2010, chapter 4)

However, Dawkins' argument seems to assume what it is trying to prove. Dawkins argues that because Darwinian evolution produces what appears to be purposeful complexity without teleology, it is possible to reduce all teleology in just this way. However, how does Dawkins know that Darwinian evolution requires no purposeful design? Let us suppose that on the level of biology, no references to design are required to explain everything. As we have seen above, it is possible to believe that while no teleology is required on the level of proximate biological explanations, Darwinism itself ultimately depends on teleology built into the universe. If the Darwinian process does depend on such teleology, then it does not work without design. To prove his premise - that Darwinian evolution does not require design, and thus works as an example of design without a designer - Dawkins therefore also has to assume his conclusion, that there is no design on the cosmic level.

Considered from the point of view of a classical theology of creation, contrasting random contingency and design seems problematic. If there are contingent events in the world, then these can only be events which are made possible by the structure of the world which God has created and which are allowed and foreseen by God. Thus teleology could be built into the Darwinian process without a logical contradiction, and we could have evidence of design in nature even if Darwinian theory is true. Ratzsch $(2001,59)$ similarly argues that "if something would constitute evidence of design in the context of some presumed gap in nature, then it will also constitute evidence of design even if the gap in question gets closed naturally". Thus Darwinism does not, according to Ratzsch, necessarily threaten the biological design argument.

\section{Combining Darwinism and Design within Intelligent Design}

Interestingly, there are ingredients within Intelligent Design which should make acceptance of this sort of combination of Darwinism and design more plausible for supporters of ID. Most clearly, the insistence that Darwinism and design are in opposed is in tension with ID's own broad definitions of design and rationality. For example, according to Phillip Johnson (2000), "reality is simply too rational and beautiful ever to be forced into 
the narrow categories that materialism can comprehend." The rationality and beauty of reality in its harmonious natural laws, the possibility of science, the fine-tuning of the universe, the complexity of biological organisms and even the glimpses of something greater in the arts and religious experience all speak of the reality of the "intelligent designer" for the ID movement. (Wiker \& Witt 2006, Gonzales \& Richards 2004, Behe 2007) For Richard Dawkins and the ID theorists, Darwinian evolutionary theory is in competition to the biological design argument, and can refute it. But doesn't this view still leave a lot of evidence for design, even from the ID theorists' perspective? It seems strange to argue that theistic evolutionism is necessarily belief in design without evidence.

Though Dembski has critiqued Simon Conway-Morris, he has later himself proposed a similar reconciliation of design and Darwinism. Dembski and Robert Marks (2009) argue that there is a law of conservation of information, which applied to biology means that "when natural systems exhibit intelligence by producing information, they have in fact not created it from scratch but merely shuffled around existing information." While evolutionary computer algorithms are often used to demonstrate the power of the Darwinian mechanism of mutation and selection to generate order, Dembski and Marks argue that such algorithms also show the limits of the mechanism. They argue that information can only be generated by evolution when it is built into the process. It is possible to generate algorithms which rely on mutations and selection and which do not generate any interesting results; algorithms where the Darwinian process works to develop useful results have to be carefully constructed by engineers. By analogy, Darwinian evolution in nature could also be understood teleologically as dependent on the information built into the structure of the world. (Dembski \& Marks 2009, 31)

Perhaps a theistic evolutionist could even argue that Darwinism does not eliminate the evidence for biological design. Material for such an argument can be found from the ID theorists' own writings. According to Benjamin Wiker and Jonathan Witt (2006, 242), understanding fine-tuning makes us appreciate the surface beauty of the world more. For example, "a rose is most meaningful to us when we understand it as a kind of dramatic culmination, one possible only because all these layers of complexity are integrated by and toward the whole, brought into harmony in and by the living form itself." But if seeing the rose's meaning is easier when one understands the cosmic fine-tuning necessary for it, the converse could also be true. The beauty, complexity and "apparent design" of the biological world could help us appreciate the remarkable nature of cosmic finetuning better. It could be argued that in a way, we see the fine-tuning through the features of biological life, thus also seeing design. Based on this idea, perhaps an argument could be developed to the effect that the order of biological organisms can still testify of a Creator, even if the proximate explanation for this order is Darwinian evolution. Similarly, Ward (2003) argues that while design is not needed scientifically, the "progress" apparent in the move from single-celled organisms to conscious life is nevertheless evidence of design from a philosophical and theological perspective.

Many of ID's arguments are construed to demonstrate that Darwinian evolution is a highly improbable explanation of the biological data. Consider Michael Behe's argument from irreducible complexity, which states that certain biological structures are composed of interdependent parts, and their evolution in a stepwise Darwinian fashion is implausible. (Behe 2006) Against the common explanation that the parts for such systems have evolved from simpler systems serving different functions, Behe (e.g. 2006, 66; 94; 113; 2007, appendix A) argues that it is unlikely that proteins which are specialized for one function just happen to be easily convertible 
to serve in another role. It seems that such evolvability is just too serendipitous to be plausible for Behe. However, suppose that such systems are indeed evolvable. An ID theorist seeking to move into a TE direction could argue that Behe's argument just goes to show how strict the conditions for the evolvability of complex systems are, and thus how much design Darwinian evolution requires.

The evaluation of such arguments in beyond the limits of this article, but the possibility of Intelligent Design's convergence with theistic evolutionism is intriguing. The reasons Dembski and Marks (2009) give for not calling their model of teleological Darwinism "theistic evolutionism" are also important. For them, theistic evolutionism is belief in teleology without evidence. Thus by providing evidence by their analogical argument, they are not engaged in a project of theistic evolutionism. The desire for scientific evidence for design is central in Intelligent Design's critiques of theistic evolutionism. But why the emphasis on scientific evidence, and couldn't one also have extra-scientific reasons for belief in theistic evolution? I will now move on to consider the fundamental assumptions behind ID's critique of theistic evolutionism.

\section{Intelligent Design and the Seduction of Scientism}

As we have seen, the ID theorists emphasize the importance of scientific evidence to defend theism against naturalism. This is foundation of their critique of theistic evolutionism. Earlier, we have seen that the ID theorists recognize the possibility that God could have directed the process of evolution, but in a way that is undetectable by the natural sciences and unnecessary for biological theories. However, this is seen as unsatisfactory for theists, because it removes evidence of design. The ID theorists recognize that is logically possible to separate Darwinism as a way of thought from Darwinism as a scientific theory - they just believe that this is in practice difficult. (E.g. West 2003, chapter 10; Wiker 2002) For example, Phillip Johnson argues that the Darwinian way of thought rules out an evidentially based belief in creation, but still leaves room for religion which is chosen for subjective reasons. (Johnson 1993, 155-157)

Dembski (1999, 110) writes that "within theistic evolution, God is a master of stealth who constantly eludes our best efforts to detect him empirically. Yes, the theistic evolutionist believes that the universe is designed. Yet insofar as there is design in the universe, it is design we recognize strictly through the eyes of faith. Accordingly the physical world in itself provides no evidence that life is designed. For all we can tell, our appearance on planet earth is an accident." In this quote, Dembski places a great emphasis on the importance of scientific evidence for design instead of philosophical and religious evidence. This implies that if we accept the Darwinian view, there are no good reasons to believe in the designedness of life's evolution or the universe at large: "for all we can tell, our appearance on planet earth is an accident."

Dembski also argues that ID is theologically valuable, because it provides evidence against a theory which is indispensable for atheists. For him, claiming that evolution implies atheism is "logically unsound", but it is not unsound to claim that “atheism implies evolution.” According to Dembski, atheists require some sort of natural explanation for the design-like complexity of the biological world in order to be "intellectually satisfied atheists". Without evolution, atheists would have a problematic amount of evidence of design, and would also lack the possibility of justifying their Darwinian metaphysics in a scientific-sounding way. By accepting Darwinian evolutionary theory, theistic evolutionists are thus not using a potent weapon against Darwinism. For Dembski, evolution is like a club which atheists are using to beat believers. He argues that ID breaks the club, 
while theistic evolutionism provides an ineffectual defence. (Dembski 2010; Dembski \& Witt 2008; influenced by Dawkins 1991)

Phillip Johnson similarly opposes the "blind watchmaker" of Darwinism and divine design. According to Johnson, evolution does leave room for a far away first cause, a deistic God. However, it doesn't leave room for a God who makes a difference in the natural world and whose existence can be seen from his works: "If God stayed in that realm beyond the reach of scientific investigation, and allowed an apparently blind materialistic evolutionary process to do all the work of creation, then it would have to be said that God furnished us with a world of excuses for unbelief and idolatry.”(Johnson 2001, 443) According to Johnson, the Bible in Romans 1:20 speaks of a nature that points "directly and unmistakably" toward the necessity of a Creator. For him, accepting Darwinian evolutionary theory means that natural revelation in biology can no longer be said to "direct and unmistakable". Biological created things can no longer be said to reveal a Creator, and a crucial piece of evidence for intelligent design has been lost. (Johnson 2001)

The insistence on scientific evidence is in tension with the ID movement's broader thought. Because this insistence is the foundation of the ID theorists' critique of TE, tensions at this point are significant. I will now proceed to consider four aspects of this tension. First, the critique seems to require scientism, which the ID theorists elsewhere reject. Second, the critique is in tension with the movement's broader goal of defending religious rationality and Christian theology. Third, the ID theorists recognize that their own argument does not prove the existence of God, and so must acknowledge the importance of non-scientific reasons for belief. Fourth, the ID theorists recognize that the design inference is pre-scientific, and thus should not be dependent on science.

First, is the ID movement's emphasis on the importance of scientific evidence a form of scientism, where religious and philosophical reasons for belief are not seen as rational and valuable? The ID theorists themselves insist that ID is not scientism. Thus William Dembski (1998, 26-27) and Jay Richards (2010, 260-270) explain the emphasis on scientific reasons as partly a strategic choice: science has immense cultural authority and far greater public credibility than religion or philosophy. It is the "only universally valid form of knowledge in our culture." (Dembski 1998, 26-27) Because of this, the ID theorists oppose the atheistic use of science by scientific arguments, rather than philosophy or religion. In challenging the scientific theory of Darwinian evolution, they want to say that their alternative is also scientific.

However, contrary to this explanation, in the ID theorists' critique of theistic evolutionism the emphasis on the necessity of scientific reasons does not appear to be merely a strategic choice. Rather, theistic evolutionism is seen as differing only superficially from naturalistic evolutionism and their philosophical and theological reasons are dismissed as unimportant. As we have seen, this is the case even in the ID theorists' evaluations of theistic evolutionists like Denis Lamoureux, who themselves insist that there is much evidence to support theism. The impression this critique gives is that the ID movement itself values scientific reasons far above religious and philosophical ones just as our broader culture does.

There is a danger in this insistence on primarily scientific reasons in defence of religious belief. From a Christian perspective, the supposition that religious and philosophical reasons for belief have little value is surely a large problem in our culture to be confronted, rather than a reality that needs to be accepted. Because of the implicit devaluing of philosophical and religious reasons in the critique of theistic evolutionism, the ID movement does seem to be at least flirting with scientism. To really defend religious beliefs, it seems that the ID movement should defend the existence of a religious rationality separate from science. Making science the 
primary arbiter of religious truths is theologically problematic, because (1) most Christian doctrines cannot be demonstrated within the narrow confines of what scientism counts as rational, and (2) religious rationality is in actual practice based on much broader grounds. Thus accepting scientism as the criterion of rationality would make typical Christian religious beliefs irrational. Furthermore, there are also substantial philosophical arguments against scientism. Science itself seems to require a broader conception of rationality. (Stenmark 2001, Vainio 2010).

Because the ID movement wants to defend traditional Christianity, it should emphasize the existence of good philosophical and religious reasons for belief in design, rather than insisting that theistic evolutionists must provide scientific evidence. Niall Shanks and Keith Green (2011) and Conor Cunningham (2010, 278) have argued that ID's project presupposes scientism. However, I find that ID's flirtation with scientism is actually in tension with its broader ideas. The ultimate theological purpose of the ID movement is actually to refute materialistic scientism, not to affirm it. Thus Dembski (1999) identifies scientific evidence for intelligent design as the "Bridge Between Science and Theology", presupposing that Christian theology is a rational enterprise. Johnson (2000) has termed the Intelligent Design movement a "wedge" which can destroy the pretensions of scientific materialism and open up room for a broader conception of rationality which includes religion and theology. Johnson's opposition to scientism is sometimes so clear that Robert Pennock (2010) actually identifies his views with postmodernism - a view which at least superficially seems quite far from scientism. Johnson's idea is that if room is made for a designer within science, then the possibility of rationality outside of science also becomes credible. But if there is rationality outside of science, then why the insistence that belief in creation absolutely must have scientific support? These premises that (1) the case for design is broader than biology, and (2) it can be rational to believe something even with non-scientific reasons, would seem to lend themselves also to the justification of a theistic view of evolution.

Dembski's argument that ID is required to counter the atheists' use of evolutionary science as an argument against religious belief is problematic for related reasons. As we have seen, both the ID theorists and theistic evolutionists recognize that the "Darwinism" used as a weapon is not just a scientific theory, but also a metaphysical worldview. But if this is true, then the weapon also has a philosophical component, and it is not composed just of science. It follows that philosophical arguments can and must be used to dismantle the weapon. Powerful philosophical arguments against materialistic scientism indeed exist (see e.g. Stenmark 2001, Cunningham 2010 and Plantinga 2011), so it is difficult to see why the ID theorists seem in many comments to see ID as the only durable answer to this use of Darwinism.

The ID theorists' arguments themselves strongly imply that rationality is not restricted to science. First, the ID theorists admit that their own design arguments do not demonstrate the existence of the Christian God, but just some kind of intelligent designer. Johnson (2007), for example, admits that "my personal view is that I identify the designer of life with the God of the Bible, although intelligent design theory as such does not entail that." Behe (2007, 277-278) writes that his argument provides evidence of design, but "the leap to God with a capital G short-circuits scholarly arguments that have been going on for millennia across many cultures." Because all of the major ID theorists nevertheless see the designer as the God of the Bible, this means that they must acknowledge some reasons for belief outside the design argument. Some such reasons are referenced in works by the ID movement. For example, the Leibnizian cosmological argument, the Kalam cosmological argument, the moral argument, the historical evidence for Jesus' resurrection and religious experience are 
mentioned (e.g. Moreland 1994, Dembski \& Licona 2010). But if the ID theorists admit that their design argument is also insufficient as a defence of the doctrine of creation and Christian belief, then what is their basis for chiding theistic evolutionists for providing insufficient evidence? If the ID theorists can have recourse to non-scientific reasons for religious belief, what is to prevent theistic evolutionists from also having recourse to these same reasons?

Second, the ID movement sees the design argument as a defence of an ancient design intuition. From antiquity, the world has appeared rational to many humans, who have also had the intuition that it is designed. For the ID theorists, just the description of the order of nature should be enough to persuade most people with common sense that there is an Intelligent Designer. According to Michael Behe $(2006,265)$ "the overwhelming appearance of design strongly affects the burden of proof: in the presence of manifest design, the onus of proof is on the one who denies the plain evidence of his eyes." According to Dembski (2005), "my mathematics is giving theoretical support to intuitions that most people have for a long time harbored." He argues that people naturally use the logic of his "explanatory filter" to perceive design, and he is just formulating our natural thought process in a rigorous and scientific way. Meyer $(2009,17)$ argues that his design argument on DNA leads to the same conclusion as "commonsense reasoning" on the matter. But if humans have found out the truth intuitively without detailed design arguments and without modern science, then it seems that belief in design actually does not depend on science. It could of course be that this natural perception of design requires a defence and further elaboration to remain credible in our modern culture. But it requires further arguments from the ID theorists to show that this defence has to be scientific rather than philosophical.

Arguably philosophical and theological responses to Darwinistic atheism are more important than ID, because the doctrine of creation is about so much more than just the question of design. The idea of God as the orderer of the cosmos is certainly a traditional part of the doctrine. For example, McGrath $(2001,155)$ argues that "the theme of ordering is of major importance to Old Testament conceptions of creation." However, in traditional Christian theology the doctrine of creation is also about much more: God is also seen as the upholder of reality and the ground of being. As Conor Cunningham (2010) has argued, the doctrine is better situated on the level of metaphysics than in competition with any scientific hypothesis.

The idea of natural revelation as spelled out in Romans 1:20, too, is a far broader matter. While Johnson (2001) relates the passage to the biological design argument, the text itself is actually quite ambiguous about the precise way God's power and wisdom are manifested. Biological and cosmic design arguments are not mentioned. The text is most closely related to the apocryphal Book of Wisdom 13:1-9, which is far from modern design arguments. For example, consider the very general nature of verses 1-3: "But all men are vain, in whom there is not the knowledge of God: and who by these good things that are seen, could not understand him that is, neither by attending to the works have acknowledged who was the workman: But have imagined either the fire, or the wind, or the swift air, or the circle of the stars, or the great water, or the sun and moon, to be the gods that rule the world. With whose beauty, if they, being delighted, took them to be gods: let them know how much the Lord of them is more beautiful than they: for the first author of beauty made all those things." While biological design does speak of the Creator for many religious thinkers, many also see the immense power and greatness of God in things like the vastness and beauty of the wide blue sky. Psalm 19 says that the heavens testify of God's greatness, but it does not present a design argument. And many feel that the success of science 
in understanding the physical processes of creation only make their amazement at God's wisdom greater, rather than diminishing it. (Roberts 2003)

\section{Resolving the Tensions}

Though the ID movement's critique of theistic evolutionism comes close to scientism, this is in tension with the movement's broader thought. The tensions are highly problematic for ID's critique of theistic evolutionism, but they are fairly easy to solve. The ID movement can abandon its critique of theistic evolutionism and turn away from the seduction of scientism without abandoning any of its core arguments. It can continue to insist on the insufficiency of Darwinian evolutionary theory and the value of scientific evidence in support of belief in creation, even while acknowledging that belief in creation does not depend on the failure of Darwinism or the existence of scientific arguments in its favour. Even within ID, there are already some examples of such a broader approach. For example, Benjamin Wiker and Jonathan Witt argue that there is evidence of design which is "Darwin-proof" (Wiker \& Witt 2004, 238) and Angus Menuge (2005) uses ID as merely a part of a broader philosophical argument against reductionistic materialism. Michael Behe accepts the coherency of theistic evolutionism, even arguing that TE John Haught actually believes in “intelligent design” (Behe 1999a).

The ID theorists may ask what value can be found in acknowledging that Darwinian evolutionary theory can be integrated into a theistic worldview. Thus Jay Richards $(2010,302)$ argues that prior to examining "such arcane possibilities" we should first ask the prior question of whether Darwinian evolutionary theory is even true. If the theory is not true, then there is no need to harmonize it with Christian belief. However, based on the above, the possibility of harmonization should be useful even from the point of view of the ID theorists. First, this would provide us with a better understanding of the basis of Christian belief, the nature of the doctrine of creation and its relationship to scientific theories. Second, a broader use of good theological and philosophical arguments would strengthen the overall argument against naturalism and scientism. Third, the theory of evolution is widely believed to be true in the academia, even by many who are acquainted with the ID theorists' critique of Darwinism. Theological and philosophical arguments could help these people avoid accepting the atheistic metaphysical interpretation of Darwinism. Fourth, the acceptance of theistic evolutionism as a philosophically and theologically defensible position would help avoid the impression that the ID theorists oppose evolutionary theory because of religious reasons.

Giving up the critiques of theistic evolutionism analysed in this article also will not mean that the ID theorists will have to give up all of their critique of TE positions. For example, they could continue to criticize the idea that classical Christianity requires Darwinian evolutionary theory to help solve the problem of natural evil (Dembski 2009, chapter 21), or that classical Christianity requires God to create the myriad forms of life without interventions into natural history. (Dembski, Downes \& Frederick 2008) My own belief on this point is similar to Collins (2009): Rather than theological considerations, the empirical evidence should be the central motivation for accepting evolutionary theory.

\section{Conclusion}


For the ID theorists, Darwinism is not just a scientific theory, but a metaphysical worldview. When theistic evolutionists try to separate between the scientific theory of biological evolution and Darwinian metaphysical ideas, proponents of ID see this as a misunderstanding of the implications of evolutionary theory. However, though ID's critique of theistic evolution implies that it is the only way to be an intellectually satisfied Christian theist, this claim can be questioned. The ID movement criticizes theistic evolutionism for not being a sufficient response to the challenge posed to theism by atheistic Darwinism. Theistic evolutionism is argued to provide too little scientific evidence against the atheistic picture of the world or in favour of the doctrine of creation. However, this critique is ultimately in tension with other aspects of Intelligent Design. Though the ID movement's ultimate goal is to oppose scientism, its critique of theistic evolutionism nevertheless comes close to succumbing to the seduction of scientism. To be consistent, the ID theorists should acknowledge that theistic evolutionists can have good broader grounds for their belief in the doctrine of creation, even if they do not ground this belief in natural science. Proponents of ID are advised to reconsider their critique of theistic evolutionism for the sake of increased coherency, thereby sharpening their arguments against materialistic atheism and widening their "big tent."

\section{References}

Ayala, Francisco. 2007a. Darwin's Gift to Science and Religion. Washington, DC: Joseph Henry Press. . 2007b. "Darwin's Greatest Discovery: Design without a Designer." Proceedings of the National Academy of Sciences. Vol. 104. Suppl. 1. 8567-8573.

Barbour, Ian. 1997. Religion and Science: Historical and Contemporary Issues. San Francisco, CA: HarperOne.

Behe, Michael. 1999a. "Review. God After Darwin: A Theology of Evolution.” Metaviews. December 4. 1999b. "Comments on Denis Lamoureux's Essays." Darwinism Defeated? The Johnson-Lamoureux Debate on Biological Origins. Ed. Phillip Johnson \& Denis Lamoureux. Vancouver, BC: Regent College Publishing. 103-108.

. 2005. "Can You Believe in God and Evolution?" Time Magazine. Sunday August 07.

2006. Darwin's Black Box: The Biochemical Challenge to Evolution. $10^{\text {th }}$ anniversary Edition. New York, NY: The Free Press.

2007. The Edge of Evolution: The Search for the Limits of Darwinism. New York, NY: The Free Press.

Comfort, Nathaniel C. Ed. 2007. The Panda's Black Box: Opening up the Intelligent Design Controversy. Baltimore, ML: The Johns Hopkins University Press.

Cunningham, Conor. 2010. Darwin's Pious Idea: Why the Ultra-Darwinists and Creationists Both Get it Wrong. London: Wm. B. Eerdmans Publishing Company.

Dawkins, Richard. 1991. The Blind Watchmaker: How the Evidence of Evolution Reveals a Universe without Design. London: Penguin books.

2006. The God Delusion. London: Bantam Press.

Dembski, William. 1998. "Introduction: Mere Creation.” Mere Creation: Science, Faith and Intelligent Design. Ed. William A. Dembski. Downers Grove, IL: InterVarsity Press.

1999. Intelligent Design: The Bridge Between Science and Theology. Downers Grove, IL: InterVarsity Press.

2002. No Free Lunch: Why Specified Complexity Cannot Be Purchased Without Intelligence. Lanham: Rowman \& Littlefield Publishers.

2005."Specification: The Pattern That Signifies Intelligence." The Design Inference. Available at $<$ http://www.designinference.com>.

. 2009. The End of Christianity: Finding a Good God in an Evil World. Nashville, TN: B \& H Academic. 
2010. "Evolution, Theistic Evolution, and Intelligent Design." Chuck Colson Center Website. <http://www.colsoncenter.org/the-center/columns/call-response/14641-perspectives-evolutiontheistic-evolution-and-intelligent-design>. Accessed on March $7^{\text {th }}, 2012$.

Dembski, W. Downes, J. and Frederick, W. Eds, 2008. The Patristic Understanding of Creation: An Anthology of Writings from the Church Fathers on Creation and Design. Riesel, TX: Erasmus Press.

Dembski, W. \& Licona, M. Eds. 2010. Evidence for God: 50 Arguments for Faith from the Bible, History, Philosophy and Science. Grand Rapids, MI: Baker Books.

Dembski, W. \& Ruse, M. Eds. 2004. Debating Design: From Darwin to DNA. Cambridge: Cambridge University Press.

Dembski, W. \& Wells, J. 2007.The Design of Life: Discovering Signs of Intelligence in Biological Systems. Richardson, TX: Foundation for Thought and Ethics.

Dembski, W. \& Witt, J. 2008. How to be an Intellectual Fulfilled Atheist (Or Not). Wilmington, DL: Intercollegiate Studies Institute.

Dembski, W. \& Marks, Robert II. 2009. "Conservation of Information in Search: Measuring the Cost of Success." IEEE Transactions on Systems, Man and Cybernetics A, Systems \& Humans, 5(5) (September 2009): 1051-1061.

Haught, John. 2003. Deeper than Darwin: The Prospect for Religion in an Age of Evolution. Boulder, CL: Westview Press.

Johnson, Philip. 1993. Darwin on Trial. $2^{\text {nd }}$ ed. Downers Grove, Illinois: InterVarsity Press. 1995. Reason in the Balance. Downers Grove, Illinois: InterVarsity Press. 2000. The Wedge of Truth: Splitting the Foundations of Naturalism. Downer's Grove, IL: InterVarsity Press. . 2001. "Creator or Blind Watchmaker?" Intelligent Design Creationism and Its Critics: Philosophical, Theological and Scientific Perspectives. Ed. Robert Pennock. Cambridge, MA: The MIT Press. 435449. 2007. "Intelligent Design in Biology: the Current Situation and Future Prospects." Think. The Royal Institute of Philosophy. February 19, 2007.

Johnson, Phillip \& Lamoureux, Denis. Eds. 1999. Darwinism Defeated? The Johnson-Lamoureux Debate on Biological Origins. Vancouver, BC: Regent College Publishing.

Johnson, Phillip \& Reynolds, John Marks. 2010. Against All Gods: What's Right and Wrong About the New Atheism. Downer's Grove, IL: IVP Books.

Koperski, Jeffrey. 2008. "Two Bad Ways to Attack Intelligent Design and Two Good Ones.” Zygon. Vol. 43. No. 2. 433-449.

McGrath, Alister. 2001. A Scientific Theology, Vol. 1: Nature. Edinburgh: T \& T Clark.

Menuge, Angus. 2004. Agents Under Fire: Materialism and the Rationality of Science. Lanham: Rowman \& Littlefield Publishers.

Meyer, Stephen. 2009. Signature in the Cell: DNA and the Evidence for Intelligent Design. San Francisco, CA: HarperOne. . 2010. "The Difference It Doesn't Make." God and Evolution: Protestants, Catholics and Jews Explore Darwin's Challenge to Faith. Ed. Richards, J. W. Seattle, WA: Discovery Institute Press. 147-164.

Monton, Bradley. 2009. Seeking God in Science: An Atheist Defends Intelligent Design. Buffalo, NY: Broadview Press.

Moreland, J.P. Ed. 1994. The Creation Hypothesis: Scientific Evidence for an Intelligent Designer. Downers Grove, IL: IVP Books.

Miller, Kenneth. 2002. Finding Darwin's God: A Scientist's Search for Common Ground Between God and Evolution. New York, NY: Harper Perennial.

Nelson, Paul. 2002. "Life in the Big Tent: Traditional Creationism and The Intelligent Design Community." Christian Research Journal. Vol 24. No 4.

Orr, Allen. 2007. “A Mission to Convert. Review of 'the God Delusion'.” The New York Review of Books. January 11.

Pennock, Robert. Ed. 2001. Intelligent Design Creationism and Its Critics: Philosophical, Theological and Scientific Perspectives. Cambridge, MA: The MIT Press. 2010. “The Postmodern Sin of Intelligent Design.” Science and Education. Vol. 19. No. 6-8. 758-778.

Plantinga, Alvin. 2007. "The Dawkins Confusion: Naturalism ad Absurdum." Books \& Culture. A Service of Christianity Today. Vol. 13. No. 2.

2011. Where the Conflict Really Lies: Science, Religion and Naturalism. Oxford: Oxford University Press. 
Ratsczh, Del. 2001. Nature, Design and Science: The Status of Design in Natural Science. Albany, NY: State University of New York Press.

. 2002. "Design Theory and Its Critics: Monologues Passing in the Night. Review Article of: Robert T. Pennock (ed.), Intelligent Design Creationism and its Critics." Ars Disputandi. The Online Journal for Philosophy of Religion. Vol. 2. Available at <http://www.arsdisputandi.org/>.

Richards, Jay W. (Ed.) 2010. God and Evolution: Protestants, Catholics and Jews Explore Darwin's Challenge to Faith. Ed. Richards, Jay W. Seattle, WA: Discovery Institute Press.

Roberts, Michael. 2003.“Intelligent Design: Some Geological, Historical and Theological Questions.” Debating Design: From Darwin to DNA. Eds. Michael Ruse \& William A. Dembski. Cambridge: Cambridge University Press. 275-293.

Ruse, Michael. 1996. But is it Science? The Philosophical Question in the Creation/Evolution Controversy. Amherst, NY: Prometheus Books.

Sedley, David. 2007. Creationism and Its Critics in Antiquity. Sather Classical Lectures 66. Berkeley, CA: University of California Press.

Shanks, Niall \& Green, Keith. 2011. "Intelligent design in theological perspective. Synthese.” Vol. 178. No. 2. 307-330.

Stenmark, Mikael. 2001. Scientism: Science, Ethics and Religion. Burlington: Ashgate Publishing Co.

Woodward, Thomas. 2003. Doubts about Darwin: A History of Intelligent Design. Grand Rapids, MI: Baker Books.

Vainio, Olli-Pekka. 2010. Beyond Fideism: Negotiable Religious Identities. Burlington, VT: Ashgate.

Van Till, Howard. 2001. “The Creation: Intelligently Designed or Optimally Equipped?” Intelligent Design Creationism and Its Critics: Philosophical, Theological and Scientific Perspectives. Ed. Robert Pennock. Cambridge, MA: The MIT Press. 487-512.

Ward, Keith. 2003. "Theistic Evolution." Debating Design: From Darwin to DNA. Ed. W. A. Dembski \& M. Ruse. Cambridge: Cambridge University Press. 261-274.

Wells, Jonathan. 2010. "Darwin of the Gaps." God and Evolution: Protestants, Catholics and Jews Explore Darwin's Challenge to Faith. Ed. Richards, Jay W. Seattle, WA: Discovery Institute Press. 117-128.

Wiker, Benjamin. 2002.Moral Darwinism: How We Became Hedonists. Downers Grove, IL: InterVarsity Press.

Wiker, Benjamin \& Witt, Jonathan. 2006. A Meaningful World: How the Arts and Sciences Reveal the Genius of Nature. Downers Grove, IL: IVP Academic. 